\title{
IKAP.P
}

JKAP (Jurnal Kebijakan dan Administrasi Publik)

Vol.22 (2), November 2018, 128-145

ISSN 0852-9213 (Print), ISSN 2477-4693 (Online)

Available Online at https://journal.ugm.ac.id/jkap

\section{Government Public Relations and Social Media: Bridging the Digital Divide on People with Social Welfare Problems}

\author{
Sri Haryanti \\ Ministry of Social Affairs of the Republic of Indonesia \\ 5hyanti01@gmail.com \\ Effy Zalfiana Rusfian \\ Faculty of Social and Political Science, Universitas Indonesia \\ effy_rusf@yahoo.co.id
}

\begin{abstract}
This study is a public relations inquiry that aims to describe the use of social media by government public relations to bridge the digital divide that affects people with social welfare problems. The research, unlike most public relations studies that by and large, focus on organizational image, reputation, communication crisis, and transparency, uses the digital divide perspective. The research uses Grunig and Hunt Public Relations model and Melvin De Fleur communication model perspectives to examine the communication processes that occur through government public relations social media. The research uses a qualitative descriptive approach to assess the communication conducted by informants. The results showed that government public relations communication through social media has not been fully able to bridge the digital divide, especially in rural areas. The digital divide creates three relates problems that affect the effectiveness of government communication with people that experience social welfare problem. Firstly, pattern of communication involves opinion leaders. Secondly, most feedback occurs indirectly while ideally, it should be direct. Thirdly, the flow of information takes place in either one or two steps, in contrast with the ideal, which should be in one step.
\end{abstract}

Keywords: communication process, digital divide, government's social media, public relations 


\section{INTRODUCTION}

Based on internetworldstat as of June 2017, Indonesia's internet penetration reached $50.4 \%$ or 132.7 million population of Indonesia (internetworldstat.com, 2017). The increase in the use of digital/electronic services such as e-mail, e-banking, elearning, e-commerce, and others, which is possible with internet access, not only makes lives easier but also enhances the quality of users directly, and even non users indirectly. Thus, $49.6 \%$ of Indonesians continue to face limited access, if at all, to internet, in other words are victims of the digital divide. One of the easiest ways to increase digital penetration in the developing world is to increase the rate of adoption and use of mobile connectivity in general, and social media, in particular. Social media has been associated with benefits that include the ability to promote and encourage higher public participation in innovations, collaboration, interaction, and consumption.

The digital divide is often characterized by the existence of inequality in the relationship between information and communication technology (ICT) within groups of individuals who face a complex social, environmental, political, and economic conditions (Ferro et al., 2010). Thus, the digital divide is a gap between people who have access to communications and information technology and have the ability to use it and those who do not have access and skill to use communications and information technology. Calderaro describes the digital divide as a gap between those who actively use and contribute to the Internet and those who are only affected by the internet (Calderaro 2010).

Meanwhile, White (2014), considers the digital divide as an epitome of the inequality of information technology adoption between developing and developed countries. In addition to relating the digital divide to socioeconomic conditions in third world countries, White also links the problem to cultural imperialism. Nonetheless, he emphasizes that access to information and communications technology is the key problem the third world faces, rather than cultural imperialism. The digital divide is divided into levels, inter alia, level one and two. The first level relates to the existence of a gap in terms of access to information and communications technologies, while the second level relates to the inability or lack of skills to using it (Corrocher and Raineri, 2010).

Nonetheless, Indonesia is not alone in this predicament. In fact, the digital divide is a global issue. Europe and America, despite having a high percentage of internet penetration that on average surpasses $80 \%$ and $90 \%$, respectively, still face the digital divide problem (Ferro et al., 2010). In Indonesia, the rugged, remote geographical condition which are compounded by a plethora of social, political, and economic problems, are contributory factors to the disparate distribution of the country's physical and human development process, which are some of the root causes of uneven digital development.

Yohanis Mallisa cited by Ariyanti (2013), attributes several factors for the existence of the digital divide in Indonesia, to include , 1) State of infrastructure, such as electricity, internet, computer, and ICT network; 2) Lack of human resources, that is human resources that does not have the ability to use ICT technology due to low education attainment, culture that does not accept innovations, and others; 3) Lack of content in the Indonesian language, existence of rural ICT users with low education level who find it difficult to adapt to foreign languages; 4) Limited internet utilization, which relates to the use of internet merely for entertainment and wasting time.

Meanwhile, Zulkarimen in Tyas (2015), cites several factors as responsible for the digital divide in Indonesia. Such factors, among others include 1) Telecommunication access; 2) Access to the internet; 3) Education attainment; 4) Language (almost $90 \%$ of internet content is in English); 5) Access in urban areas is better than in the village. Extant literature shows a shift in the attention of researchers of the concept of digital divide from time to time. In the past, the digital divide was generally understood as referring to inequality of access to information and communications technology. With time of other concepts that are derived from digital divide such as access di- 
vide, participation divide, device gap, information divide, and usage gap have emerged.

A good example is the June Ahn (2011) study, which emphasizes the concepts of the digital divide in relation to inequality of access and participation in the use of social media among adolescents. Ahn (2011), questions whether or not there is a difference in access to new media technologies. In addition, Ahn applies the theory of digital divide on young people, within the context of online social media network. The research used demographics as some of the variables. . The research concluded that the digital divide among teenagers as reflected in the existence of a participation gap) showed a downward trend (decreased). Thus, access to social media by adolescents contributes to the decrease in the social media participation gap.

Recent research has come up with several new digital divide concept, one of which is the affordance concept. The research focused on two levels of digital divide. The first level relates to motivation and access, which concerns members of society who have access to internet and those who do not have such access and factors responsible for that. The second level concerns the usage divide, which refers to the difference in behavior in using the internet within a particular social group. Like Ahn (2011) study, the study also included demographic factors as variables. Research results concluded that that there is an association between differences in demographic factors and device sophistication; found a relationship between differences in demographic factors and smartphone usage; and income of users as a significant predictor of internet usage. The implication is that economically underprivileged groups in society are the most dependent on smartphone usage (Tsetsi and Rains, 2017).

Meanwhile, some extant research investigated the relationship between social media and human resources within the context of reducing the digital divide. One such research was conducted on Pekalongan City. The results of the research indicated the existence of a significant influence of the use of social media and human resources on the digital divide in Pekalongan City (Tyas et al., 2015). In another study on digital divide, Brown (2014) highlights the impact of the adoption of social media by nonprofit organizations on mitigating digital divide as reflected in political participation among immigrants, included demographics factors as research variables. The results showed that using social media as a political advocacy tool helps in reducing the digital divide. That said, the study showed the limited effectiveness of using social media as a political participation tool among social groups that are rare users of social media such as the elderly.

The four studies above are examples of various studies on the use of social media in bridging the digital divide, in general. The results of the studies show an association between the use of social media or digital technology and digital divide. Nonetheless, the key limitation of the above studies is that all tackled one actor, for instance the message recipient one concept of digital divide, hence paid little attention to influence other digital concepts and parties have on the digital divide. Specifically, the above research failed to take into consideration the message production-reception relationship in an integrated manner, and how that influences the digital divide.

This research is motivated by the phenomenon of digital media popularity, especially social media as a platform that has had fundamental impact on communications practice globally (Philips \& Young, 2009; Brown, 2009; Scott and Jacka, 2011; Kaul and Choudhri, 2015; Vistbacka, 2017). This is corroborated by Kusumasari's finding (2014) that correspond to Forrester Research study (1999), which noted that for many people social media is a major way of communicating and render face-to-face interaction unnecessary. According to Philips and Young (2009), "social media are micro websites that allow people to exchange interactive content within a network of friends through personal profiles or through blogs and comment lists". Meanwhile, according to USAID (2014), social media has changed how people work, and offers opportunities to collect and share news and bring changes through interaction in the audience that occurs on the Web in real-time through social 
networking.

The shift from conventional public relations to digital public relations can be regarded as one significant impact that social media has had on the practice of global communication. It is thus imperative for every public relations practitioner to be cognizant of ubiquitous and real-time nature of online communications that can change very quickly and unexpectedly. It is no exaggeration to argue that that popularity of an organization today depends in part on its its ability to extend the use of the internet and become part of the Internet culture (Philips and Young, 2009). To that end, public relations practitioners can no longer ignore the existence of social media as a new arena that brings together various groups in society, making it an important communication channel for public sector public relations purposes. It is not surprising therefore that, today, many agencies ranging from the central government to local governments in Indonesia are actively involved in using social media.

The Indonesian government uses social media for various purposes including disseminating government information, forging collaboration with the general public, and providing real-time online services. Through social media, government agencies, citizens, and business organizations are connected in producer-consumer or prosumer arrangements (Khan, 2017). Meanwhile, according to Nepal, Paris, and Georgakopoulos (2015), the domain of social media usage in the government sector takes various forms that include delivery of community services; disaster management (including disaster resilience management/ disaster early warning systems ); in transportation domains; government policies and plans; transformation of government in which social media plays a vital role in informing, mobilizing and creating communities, enhancing transparency and seeking to hold governments accountable; and for campaigns.

Social media has significant impact on the government sector, especially in the realm of communicating and disseminating government information (Nepal, Paris, and Georgakopoulos, 2015). In other words, for the government, social media is more than just tweets, posts, likes, and shares, but reflects the extent to which the conduct of public services is based on principles of transparency, sharing, openness, and collaboration (or fostered) by social media. In other words, social media should not be limited to establishing a social media presence (by for example creating a Facebook fan page or a government Twitter account), but should be complemented by a promoting a culture of sharing $(\mathrm{S})$, transparency $(\mathrm{T})$, openness $(\mathrm{O})$, and collaboration $(\mathrm{C})$, which Khan prefers to call the STOC culture (Khan, 2017).

Studies of social media hype in public relations practice has raised questions among practitioners, public relations academics and communications organizations. Numerous studies have examined the use of social media by public relations as a means of communication to enhance organizational image (Adhrianti, 2016), reputation (Kaul and Choudhri, 2015), crisis management (Vistbacka, 2017), and as a manifestation of engagement in participation and transparency through in the deployment of egovernment practice (Riastika, 2014; Graham, 2014; Gunawong, 2016; Rosario et al., 2018; Munandar and Suherman, 2016).

With respect to previous research on social media, not a few studies have been conducted on efforts by governments to use the media in public relations which are tailored toward shaping the image, reputation, and as an indication of government transparency to the mass media, as well as a channel to showcase government commitment to the implementation of digital government. Nonetheless, there is no extent research that specifically tackles the issue of using social media as a government public relations exercise to reduce the digital divide To that end, the objective of this research is to investigate the impact of the use of social media in government public relations activities on the digital divide in society.

It is interesting to note, at the outset that some results of research on the relationship between social media use and the digital divide do not show any impact. In other words, the hypothesis that the use of social media reduces the level of digital divide is 
not accepted. In many instances, the adoption of digital technology in general and social media in particular in society with the aim of reducing the digital divided often faces social, economic and cultural conditions that hamper its effectiveness in that respect. For example, using social media among elderly migrant voters was found to be ineffective in reducing the digital divide (Brown, 2014). The lesson from Brown (2014) research is that adopting social media or other digital technology to reduce the digital divide must be done in such a manner that takes into consideration social, economic, cultural even political-economy context of the polity where it is adopted. Moreover, the digital divide also hampers the effectiveness of public relations in performing its function as a liaison between the government and the citizenry. This study investigates use of digital media (specifically social media), as a medium of communications and information exchange between various parties with the purpose of bridging the digital divide. Specifically, the study focuses on the adoption of digital technology and practices by such underprivileged groups of society due to poverty and various forms of disabilities. Thus, achieving equality of information access and use for social groups, which is vital for individual and group welfare becomes a big challenge. This indeed is the problem that the Public Relation Bureau of the Ministry of Social Affairs, which is charged with enhancing the welfare of all citizens faces. One of the social groups is the category of individuals who are afflicted by social perversions (Penyandang Masalah Kesejahteraan Sosial or PMKS). There are 7 groups of PMKS in Indonesia, inter alia the poor, neglected; disabled; socially stigmatized (outcasts) due to behavioral perversions and aberrations; disaster victims; alienated; and victims of violence, marginalization, trafficking, exploitation and discrimination (Strategic Plan of Ministry of Social Affair Year 2015-2019). Needless to add, with the exception of drug users who often hail from well-to-do families, most PMKS members have no access to digital media.

Specifically, the objective of this research is to analyze the impact of the use of social media (twitter, Facebook, and Instagram) as an interactive communications me- dium in the conduct of Public Relations in the Ministry of Social Affairs with the goal of bridging the digital divide among PMKS members most of who have limited access to social media. In the event the use of social media to bridge the digital divide between PMKS and other members of society is not effective what is the pattern of feedback, communications and information dissemination does public relations activities conducted by the Ministry of Social Affairs through social media take. This study used the Grunig and Hunt's public relations models to map the pattern of social media interactivity of the Ministry of Social Affairs in conducting its activities. Meanwhile, Melvin De Fleur communications model which explores the communication patterns that are formed was used to examine and describe the two way interactivity of social media. The concept of the digital divide can be regarded as one of the obstacles to effective communication (due to the existence of noise) in Melvin De Fleur model. The study assesses the use of Twitter, Facebook, and Instagram social media platforms, in the conduct of public relations in the Ministry of Social Affairs because of the high social interactivity of the three platforms.

\section{Grunig and Hunt's Public Relations Mod- els}

Grunig and Hunt developed four public relations models based on communication, research, and ethics. Model development was informed by an analysis of public relations development history (Baskin and Aronoff, 2012). The four model theory focuses on the way communication flows occur, emphasize research results based communications strategies on, and communication process that takes into account ethical or unethical aspects. The following is a brief explanation of the Grunig and Hunt public relations model (Theaker, 2004):

a. Press agentry/publicity model. In this model, public relations works like press agents that create news with the aim to influence the public, and truth is not an absolute requirement. The purpose of PR practice is to promotion, publicity, manipulation, and public propaganda. This model is often associated with business 


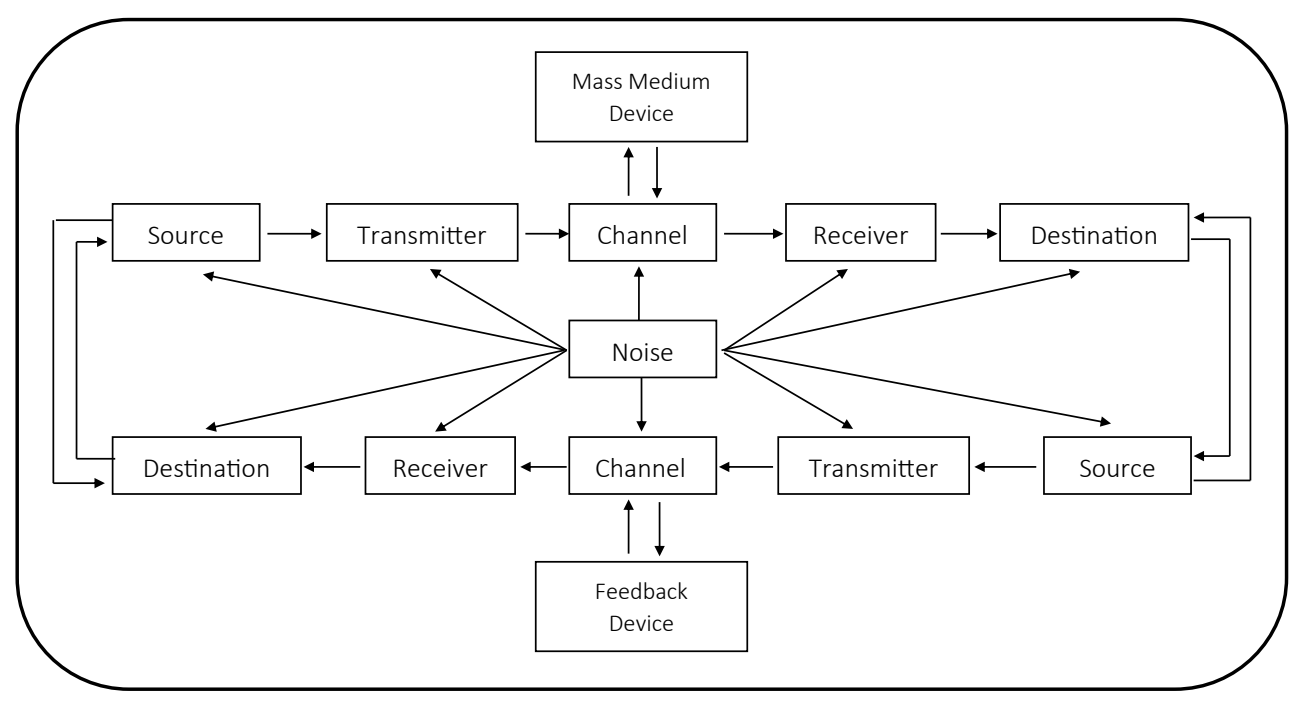

Figure 1. Melvin DeFleur Communication Model

Source : Djuarsa, 2008

segments, also known as celebrity PR

b. Public information model. Public relations communication practice based on this model is a one-way process that aims to provide relevant and accurate information to people who need it. The model does not attempt to persuade or change attitude of the audience, and is akin to the work of an in-house journalist. This model is applied in many government sectors, at the central and local government level.

c. The two-way asymmetric model. The model is based on a two-way communication process that recognizes the concept of feedback, but is unbalanced or asymmetrical due to the emphasis that it puts on persuasion and behavioral change in the audience rather than changes in the organization, for example, during health campaigns. The model is widely used in many the advertising sector as well as in some government sectors and political organizations.

d. The two-way symmetric model. This is an ideal model, which is rarely used in in public relations practice. In the model each party seeks to change its own behavior to accommodate the needs of others, model fosters the existence of a balanced dialogue or reciprocal communication. The model has the goal of achieving mutual understanding among parties in- volved in the communications exercise. .

Based on Grunig, Grunig, and Dozier (2002) acknowledgement, the four model theory is a useful research tool for analyzing public relations practices in various situations as well as helps to explain factors behind the conduct of public relations practice in different ways in various organizations. In the first model (publicity), press practitioners use all means to seek public attention to the organization. Meanwhile the second model, public information practitioner serves the role of a journalist-in-residence who is tasked with disseminating objective information about the organization to the public. Thirdly, in a two-way asymmetry model, practitioners undertake scientific research to determine ways that are used to convince people to behave in accordance with expectations and interests of the organization. In the two-way symmetry model, research and dialogue occur, generate symbiotic changes in ideas, attitudes of organizational and public behavior (Grunig, Grunig, and Dozier, 2002).

\section{Melvin DeFleur Communication Model}

In order to understand the DeFleur communication model, firstly, it is necessary to be knowledgeable about Shanon-Weaver (one-way) and the Westley-Mclean (twoway) models. This is due to the fact that Melvin DeFleur communication model con- 
Sri Haryanti, Effy Zalfiana Rusfian - Government Public Relations and Social Media....

Table 1. The Result of Platform Observation

\begin{tabular}{lcccccc}
\hline $\begin{array}{l}\text { Platform/ } \\
\text { Followers Amount } \\
(\mathbf{1 0} \text { November 2017) }\end{array}$ & $\begin{array}{l}\text { Total } \\
\text { Post }\end{array}$ & $\begin{array}{l}\text { Reaction/ Comment/ } \\
\text { Favorite } \\
\text { Reply }\end{array}$ & $\begin{array}{l}\text { Share/ } \\
\text { Retweet }\end{array}$ & $\begin{array}{l}\text { Total } \\
\text { Content }\end{array}$ & $\begin{array}{l}\text { Respond to } \\
\text { Comment }\end{array}$ \\
\hline $\begin{array}{l}\text { Facebook } \\
(4,502)\end{array}$ & 16 & 1.403 & 196 & 290 & 81 & 11 \\
\hline $\begin{array}{l}\text { Twitter } \\
(66,147)\end{array}$ & 93 & 1.725 & 297 & 905 & 130 & - \\
\hline $\begin{array}{l}\text { Instagram } \\
(38,791)\end{array}$ & 7 & 3.010 & 551 & 5 & 9 & 2 \\
\hline Total & & & & & & \\
\hline
\end{tabular}

Source : Data analysis

stitutes an evolution and improvement of the two communication models. In other words, DeFleur model is a combination of the communication models to create a more complete communication model that describes the communication process. The Shannon-Weaver model is based on information theory that describes the communication process as a one-way linear process (Vardiansyah, 2004). Transmitters or channels and noise or interference are two important elements in the Shannon-Weaver model. The model is the first one that incorporates the role of technology in the field of communication science studies, and equips communications practitioners with knowledge of how the communication process occurs in certain situations (Butterick, 2013). Nonetheless, because of the linear nature of the model, many consider it unable to sufficiently explain the complexity of the reality of the communication flow that occurs. To that end, DeFleur communication model is considered to be complementary to Shannon-Weaver model. This is attested by the fact that DeFleur model adds the feedback element to the Shannon-Weaver model, which enables it to offer a two-way circular communication model.

Meanwhile, in the Westly-McLean model, communication occurs in a twostage process that involves mass media and opinion leaders (Vardiansyah, 2004). In ad- dition, the Westley-Mclean model, while allows feedback through mass media or opinion leaders, excludes the involvement of communication transmitters or technology components. To that end, DeFleur model which incorporates elements in both the Shannon-Weaver and the Westly-Mclean models makes it a complete communication model. Consequently, this research used and adopted Melvin DeFleur communication model as it incorporates social media that represents communication technology; interactivity, which is part of a two-way communication process, and the digital divide as noise or communication interference elements. Thus, using Melvin DeFleur model to examine the impact on digital divide arising from the use of social media by the public relations division of the Ministry of social affairs to disseminate and deliver its programs and policies to members of people who are afflicted by social problems. In detail, the model describes a two-way communication process that involves mass media (see Figure 1), consists of eight communication components, inter alia, the communication source, transmitter, channel(medium), receiver, destination, noise, mass media device, and feedback device (Sendjaja, 2008). The model espouses the notion that the communication process is circular as it begins at the source that produces the message, goes through then transmitter that is responsible 
for the transmission signal, after which the massage is sent to the mass media (channel). Subsequently, the message is sent to the receiver, who is the destination and target. The mass media channel provides message delivery to the final destination as well as collection point for feedback from message recipients, which subsequently channels it to the source of the information (Sendjaja, 2008). In other words, one important aspect of the model is the issue of noise, which can occur at any stages of the communication process.

\section{METHOD}

This research used qualitative and descriptive approaches to collect, analyze, and interpret data. The research design was based on Grunig and Hunt, and Melvin DeFleur communications models. Purposive sampling technique was used to select informants based on their experience and knowledge of the issues that formed the core of the study (use of social media in dissemination of public information. In-depth interviews were used to collect information from key informants, who had been classified in accordance with the categories identified as relevant in the communication process during the theoretical and empirical framework. The selection of the research sample was chosen by using where the sample was taken in accordance with the identification of categories relevant to the research theme (Neumann, 2013; Daymon and Holloway, 2011). Key informant categories included social media communication practitioners (five individuals); social media administrators (three individuals); publication and news practitioners, who are charged with the task of managing communication through social media in Bureau of Public Relations, Ministry of Social Affairs (one individual). The last informant is the management of street children Foundation in Purwakarta area.

Besides primary data, the research collected secondary data obtained by observing the conduct of public relations using social media (Twitter, Facebook, and Instagram) in the Ministry of Social Affairs. The research period was limited to October 1-
November 10, 2017. Meanwhile, data analysis was based on the thematic analysis technique. Data validity was tested using triangulation of data sources to obtain a comprehensive picture of the communication process by taking into account three perspectives of the three key components of the communications process: opinion leaders as communication recipient, the medium (social media accounts of the public relations division in the Ministry of Social Affairs), and communications message producer.

\section{FINDINGS AND DISCUSSION}

This section presents research results that are based on observation of social media accounts of the Public Relations division, Ministry of Social Affairs and outcome of in-depth interviews with key informants.

Results from observation of official Twitter, Facebook, and Instagram accounts of the Public Relations division, Ministry of Social Affairs, showed that the communication process is by and large, one way, hence not interactive. This is evident in Table 1 which depicts an imbalance between the number of comments from users and responses from Public Relations division. It is also important to note, that clear observation of comments from users predominantly relates to issues that concern the recruitment process of new entrants into the public service as well as cash transfer program assistants (Pendamping PKH/PKH assistant). Thus, questions and responses of social media accounts that belong to the public relations division, Ministry of social affairs, seldom relate to PMKS issues, which is the focus of this study, but employment opportunities in Non PMKS programs that are implemented by the Ministry of social affairs.

Table 2 illustrates the formulation of the four main concepts of the communications process that is conducted by the Public Relations (PR) division, of the Ministry of Social Affairs through social media, the ability of social media to bridge the digital divide that PMKS face, other components of the communication process which PR division has conducted with PMKS in social media, and the impact that communication 
Table 2. Research Results

\begin{tabular}{|c|c|c|c|c|c|}
\hline Concept & Informant 1 & Informant 2 & Informant 3 & Informant 4 & Informant 5 \\
\hline \multicolumn{6}{|c|}{ The core concept 1: The communication process of Ministry of Social Affairs } \\
\hline $\begin{array}{l}\text { Nature of com- } \\
\text { munication }\end{array}$ & $\begin{array}{l}\text { tend to be one- } \\
\text { way, public in- } \\
\text { formation }\end{array}$ & $\begin{array}{l}\text { tend to be public } \\
\text { information }\end{array}$ & $\begin{array}{l}\text { Public infor- } \\
\text { mation, }\end{array}$ & $\begin{array}{l}\text { public infor- } \\
\text { mation, }\end{array}$ & \\
\hline Interactivity & $\begin{array}{l}\text { tend to be one- } \\
\text { way, interactive } \\
\text { is still low. }\end{array}$ & not interactive yet & $\begin{array}{l}\text { interactive is } \\
\text { still low. }\end{array}$ & $\begin{array}{l}\text { still not interac- } \\
\text { tive }\end{array}$ & \\
\hline Feedback & $\begin{array}{l}\text { Still less feed- } \\
\text { back }\end{array}$ & $\begin{array}{l}\text { There are feedback, } \\
\text { but a few }\end{array}$ & $\begin{array}{l}\text { Still lack of } \\
\text { feedback }\end{array}$ & $\begin{array}{l}\text { Feedback is } \\
\text { still stagnant }\end{array}$ & $\begin{array}{l}\text { through the } \\
\text { foundation }\end{array}$ \\
\hline $\begin{array}{l}\text { Communication } \\
\text { pattern }\end{array}$ & $\begin{array}{l}\text { two communica- } \\
\text { tion patterns, } \\
\text { through digital } \\
\text { media and that } \\
\text { involve interper- } \\
\text { sonal communi- } \\
\text { cation }\end{array}$ & $\begin{array}{l}\text { two-step communi- } \\
\text { cation, through } \\
\text { opinion leaders and } \\
\text { direct communica- } \\
\text { tion between } \\
\text { PMKS and digital } \\
\text { media public rela- } \\
\text { tions }\end{array}$ & $\begin{array}{l}\text { communication } \\
\text { flow direct and } \\
\text { two-step com- } \\
\text { munication in- } \\
\text { volving PKH or } \\
\text { TKSK assistant }\end{array}$ & $\begin{array}{l}\text { Two-step com- } \\
\text { munication } \\
\text { takes place } \\
\text { through the } \\
\text { opinion leaders }\end{array}$ & $\begin{array}{l}\text { PMKS com- } \\
\text { municates } \\
\text { directly, or } \\
\text { via telephone } \\
\text { if any. }\end{array}$ \\
\hline $\begin{array}{l}\text { Mechanism of } \\
\text { digital media } \\
\text { communication } \\
\text { PR with PMKS }\end{array}$ & $\begin{array}{l}\text { Two-step inter- } \\
\text { active communi- } \\
\text { cation mecha- } \\
\text { nism. Feedback } \\
\text { occurs directly } \\
\text { and two-step } \\
\text { mechanism }\end{array}$ & $\begin{array}{l}\text { Direct and two-step } \\
\text { mechanism, Like- } \\
\text { wise Feedback } \\
\text { occurs through a } \\
\text { direct mechanism } \\
\text { and two-step mech- } \\
\text { anism }\end{array}$ & $\begin{array}{l}\text { Direct and two- } \\
\text { step mechanism } \\
\text { Likewise Feed- } \\
\text { back occurs } \\
\text { through a direct } \\
\text { mechanism and } \\
\text { two-step mech- } \\
\text { anism }\end{array}$ & $\begin{array}{l}\text { Direct and two- } \\
\text { step mechanism } \\
\text { Likewise Feed- } \\
\text { back occurs } \\
\text { through a direct } \\
\text { mechanism and } \\
\text { two-step mech- } \\
\text { anism }\end{array}$ & $\begin{array}{l}\text { Communica- } \\
\text { tion generally } \\
\text { takes two } \\
\text { steps, two- } \\
\text { step feedback }\end{array}$ \\
\hline
\end{tabular}

Core Concept 2: The ability of social media to bridge the digital divide

\begin{tabular}{|c|c|c|c|c|c|}
\hline $\begin{array}{l}\text { The role of dig- } \\
\text { ital media in } \\
\text { dealing with the } \\
\text { digital divide }\end{array}$ & $\begin{array}{l}\text { still can not } \\
\text { bridge the digital } \\
\text { divide }\end{array}$ & $\begin{array}{l}\text { not yet one hun- } \\
\text { dred percent bridg- } \\
\text { ing the digital di- } \\
\text { vide }\end{array}$ & $\begin{array}{l}\text { not yet able to } \\
\text { bridge the digi- } \\
\text { tal divide di- } \\
\text { rectly }\end{array}$ & $\begin{array}{l}\text { pushing toward } \\
\text { two-way or } \\
\text { interactive } \\
\text { communica- } \\
\text { tion. }\end{array}$ & $\begin{array}{l}\text { Not yet bridge } \\
\text { the digital } \\
\text { divide. Rarely } \\
\text { use social } \\
\text { media }\end{array}$ \\
\hline $\begin{array}{l}\text { Social media } \\
\text { public relations } \\
\text { coverage of } \\
\text { PMKS }\end{array}$ & $\begin{array}{l}\text { social media can } \\
\text { only reach } \\
\text { PMKS who have } \\
\text { gadgets. }\end{array}$ & $\begin{array}{l}\text { PMKS in rural } \\
\text { areas remains in- } \\
\text { fluenced by social } \\
\text { media indirectly } \\
\text { from the assistant }\end{array}$ & $\begin{array}{l}\text { Reaching } \\
\text { PMKS who } \\
\text { have a gadget } \\
\text { only }\end{array}$ & $\begin{array}{l}\text { Digital media } \\
\text { coverage of } \\
\text { PMKS depends } \\
\text { on demograph- } \\
\text { ic conditions }\end{array}$ & $\begin{array}{l}\text { communica- } \\
\text { tion via email } \\
\text { and phone. } \\
\text { Rarely } \\
\text { through social } \\
\text { media }\end{array}$ \\
\hline
\end{tabular}

\begin{tabular}{|c|c|c|c|c|c|}
\hline $\begin{array}{l}\text { Opinion leader } \\
\text { role }\end{array}$ & $\begin{array}{l}\text { information Con- } \\
\text { veyor to PMKS }\end{array}$ & $\begin{array}{l}\text { information trans- } \\
\text { mitter to remote } \\
\text { areas }\end{array}$ & $\begin{array}{l}\text { disseminate } \\
\text { information }\end{array}$ & $\begin{array}{l}\text { one of commu- } \\
\text { nication bridge }\end{array}$ & $\begin{array}{l}\text { Information } \\
\text { conveyor }\end{array}$ \\
\hline $\begin{array}{l}\text { Interpersonal } \\
\text { communication } \\
\text { involvement }\end{array}$ & $\begin{array}{l}\text { occurs between } \\
\text { opinion leaders } \\
\text { and PMKS in the } \\
\text { rural area }\end{array}$ & $\begin{array}{l}\text { communication } \\
\text { occurs through } \\
\text { digital media and } \\
\text { interpersonal com- } \\
\text { munication }\end{array}$ & $\begin{array}{l}\text { communication } \\
\text { through infor- } \\
\text { mation technol- } \\
\text { ogy and inter- } \\
\text { personal com- } \\
\text { munication }\end{array}$ & $\begin{array}{l}\text { Interpersonal } \\
\text { communication } \\
\text { occurs through } \\
\text { PKH assistant } \\
\text { and PMKS }\end{array}$ & $\begin{array}{l}\text { Interpersonal } \\
\text { communica- } \\
\text { tion between } \\
\text { opinion leader } \\
\text { and PMKS }\end{array}$ \\
\hline
\end{tabular}




\begin{tabular}{|c|c|c|c|c|c|}
\hline $\begin{array}{l}\text { Involving Con- } \\
\text { ventional media }\end{array}$ & $\begin{array}{l}\text { still used as a } \\
\text { medium of pub- } \\
\text { lic relations com- } \\
\text { munication }\end{array}$ & $\begin{array}{l}\text { still used as a me- } \\
\text { dium of public } \\
\text { relations communi- } \\
\text { cation }\end{array}$ & $\begin{array}{l}\text { billboard adver- } \\
\text { tising, and in- } \\
\text { formation from } \\
\text { PKH and TKSK } \\
\text { assistant }\end{array}$ & $\begin{array}{l}\text { Conventional } \\
\text { media often } \\
\text { takes news or } \\
\text { themes from } \\
\text { social media }\end{array}$ & $\begin{array}{l}\text { direct com- } \\
\text { munication, } \\
\text { or by tele- } \\
\text { phone if } \\
\text { PMKS has } \\
\text { a telephone }\end{array}$ \\
\hline
\end{tabular}

\begin{tabular}{llllll}
\hline Core Category 4: & The cause of digital divide among PMKS \\
\hline $\begin{array}{l}\text { Cause of digital } \\
\text { divide }\end{array}$ & $\begin{array}{l}\text { Lack of ability to } \\
\text { have gadgets }\end{array}$ & $\begin{array}{l}\text { Socio-economic } \\
\text { aspect, region, lack } \\
\text { of access / BTS etc. }\end{array}$ & $\begin{array}{l}\text { Factor inability } \\
\text { to have gadgets }\end{array}$ & $\begin{array}{l}\text { socioeconomic } \\
\text { conditions and } \\
\text { gadget owner- } \\
\text { ship }\end{array}$ & $\begin{array}{l}\text { The gadget } \\
\text { ownership } \\
\text { factor }\end{array}$
\end{tabular}

Source : Data analysis

exchange has had on the level of digital divide that PMKS face As mentioned above, this research uses Grunig and Hunt and Melvin De Fleur Public Relations communications models to describe the communication process and the impact it has had on the digital divide affecting PMKS.

\section{Using Grunig and Hunt Model to describe the Social Media PR, Ministry of Social Affairs targeting PMKS}

James Grunig and Todd Hunt model categorize of the implementation of public relations based on the communication process to the public. This research describes results of the categorization process applicable to the communications activities conducted by the Public Relations division of the Ministry of Social affairs with the PMKS members using social media.

a. The Nature of Communications flow through social media

Most individuals who face social welfare problems do not have access to social media platforms that the public relations division, Ministry of Social Affairs, uses in its communications services. Thus, the communication process that takes place is one way Based on results of interviews with four informants, it was revealed that while it is undeniable that public relations communications conducted by the Ministry of Social Affairs through social media has been able to reach some PMKS members, it is also apparent that the unidirectional nature of such communications means that is not effective as a communication medium due to limited reach to the potential audience. Moreover, limited reach of the communica- tions medium also hampers feedback, which reduces the ability to measure the level of its effectiveness as a communications tool. Most PMKS who live in remote areas still rely on conventional media (telephone, brochures, or leaflets) as well as conducting direct communications through Sub-District Social Welfare officers (PKH and TKSK) as source of information on government programs and policies.

'Social media can reach PMKS especially in urban areas, even then not all of them. The situation is rural areas, is starkly different. PMKS in rural areas do not have access to digital media, and depend on information from $P K H$ or TKSK assistants as a source of information on government programs and directions (Interview with Head of Publications and News Section, Ministry of Social affairs).

Another informant, who is a staff member of the Public Relations division, Ministry of Social Affairs corroborated the above finding:

'Digital media can't reach most PMKS members as it is limited to those who have digital gadgets. Thus, social media can't fully bridge the digital divide directly but should work hand in hand with PKH and TKSK assistants or opinion leaders'.

b. Feedback through official social media accounts of the Ministry of Social Affairs

Results from interviews with informants disclosed information that showed scanty feedback information from PMKS to communications disseminated through social media by public relations division of the 
Sri Haryanti, Effy Zalfiana Rusfian — Government Public Relations and Social Media....

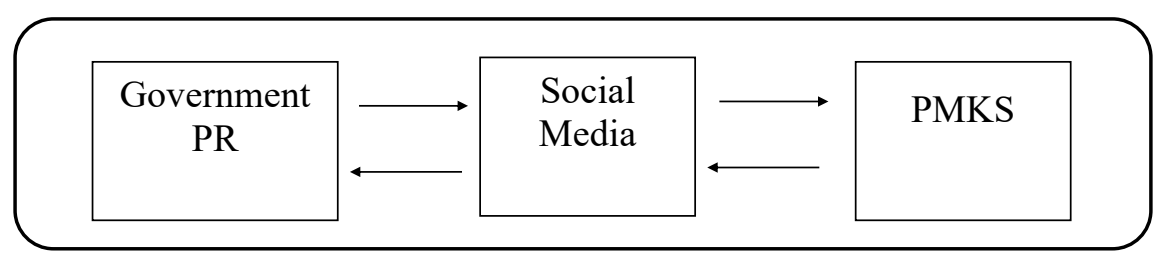

Figure 2. Flow of Information I

Source : Data analysis

Ministry of Social Affairs. Most of the information is one way, hence has its source from PKH and TKSK assistants Tagana (Disaster Response Cadets), and members of the general public. Feedback, which Public Relations division Ministry of Social Affairs receives, often is in the form of complaints from foundations or non-governmental organizations conveyed through dumas online and lapor.go.id web platforms. To that end, comments or complaints from the general public and other targets of public relations communications are rarely conveyed through social media accounts. Meanwhile, even in some cases where PMKS members in urban areas have social media accounts hence can have direct communication with the Ministry of Social Affairs through social media, it is the PKH, TKSK, Tagana, and youth organizations who serve as vital intermediaries in the communication between the Ministry of Social Affairs and PMKS members. This was as much acknowledged by one of the key informants who noted that:

"PKH and TKSK assistants are the mouthpiece of the social ministry, yes they are our hands in the rural area". (Interview with GPR, Ministry of Social Affairs).

The problem is that even in cases where recipients of communications from the public relations division give feedback, bureaucratic obstacles in the Ministry hamper response from the ministry. This is because those individuals who are charged with managing social media accounts that belong to the Ministry of Social Affairs do not have the authority to provide answers to complaints they receive from social accounts users. This leads to ignoring complaints and feedback, leading to communication atrophy.

\section{c. Interactivity}

Observation of twitter, facebook, and instagram accounts of the PR division, Ministry of Social Affairs, coupled with an assessment of interviews with informants who are charged with managing the social media accounts, researcher reached the conclusion that communication between the PR. Ministry of Social affairs and PMKS is still extremely lacking. Excerpts of interviews provide ample evidence of that. One of the informants noted that:

\section{"Communication conducted} through social media accounts of the public relations division, Ministry of Social Affairs, is by and large, a oneway process. The communication conducted by the ministry takes the form of information about its activities for the consumption of the general public. There is thus no interactivity in the communication process due to absence of a two way interchange of information between providers and recipients. Interactivity with PMKS is extremely small" (excerpt of an Interview with PR Staff).

The head of publications and News in the Ministry of social affairs confirmed such fears by saying that:

"Actually, communication with PMKS through social media, provides an opportunity for directly dealing with target audience. However, Public Relations division has not yet created conditions that support interactivity between Ministry officials (programs and policies) and PMKS members and groups. This especially the case in urban areas where $P M K S$ members have digital gadgets and social media accounts of their own 


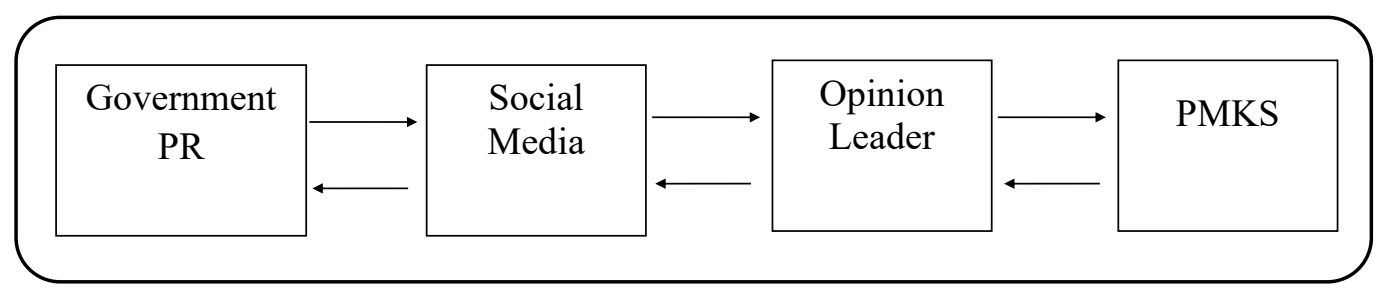

Figure 3. Flow of Information II

Source : Data analysis

that enable them to communicate them directly with ministry officials through social media." (Interview-Head of Publication and News Section)

Meanwhile, another informant, who is a staff member in the PR division, Ministry of Social affairs, had the following to say in relation to the issue:

"It (communications) should be interactive because social media provides chatting and user-friendly features for anyone. But because many PMKS do not have gadgets, interactivity is still small" (Interview-PR Staff).

Another official in the PR division, Ministry of Social affairs official concurred by noting that:

"The official social media of the Public Relations division, Ministry of Social Affairs is still not interactive because it largely depends on the socioeconomic condition that PMKS face in general and limited and in many cases, lack of access to internet. The bureaucracy pathologies that afflict PR organizational structure, compounds the problem even further." (Interview-PR Staff at the Ministry of Social Affairs).

Based on the results above, it can be concluded that the communications process, which Public Relations Ministry division of the Ministry of Social Affairs undertakes using social media with the members of the general public in general and PMKS) in particular, is till based on the public information model. Such finding is not surprising because in the model is the communications approach of choice for many public sector organizations, deliberately or otherwise. Nevertheless, the advent of digital technology is creating a shift in the pattern of communication in the public sector, which is facing calls for enhanced participation and engagement of all stakeholders in the public policy process. To that end, despite the fact that the use of social media by the Ministry of social affairs in conducting communications with PMKS has not directly contributed to reducing the digital divide the social group faces except PMKS who live in urban areas, the process is reducing the digital divide indirectly, through opinion leaders who have digital gadgets and access to social media.

To support that conclusion, one of the interesting finding is that the increasing use of social media by the general public has created opportunities for highlighting and putting spotlight on social welfare issues in news agenda. This is a departure from the past when other more sensational and attention grabbing issues such as, terrorism and political issues dominated mass media new headlines and opinions. Thus, the use of social media can help in bridging the gap in news agenda, even if indirectly, as well as affords the opportunity for PMKS who have access to internet to obtain information by connecting directly with social media platforms that are managed by the Ministry of Social affairs. Thus, despite the fact that communications through social media is still a one way process, hence is based on the interests and intentions of the provider (the Ministry of Social affairs), it can contribute to a decrease in digital divide both directly and indirectly.

Public Relations, Ministry of Social Affairs Communication Process with PMKS 


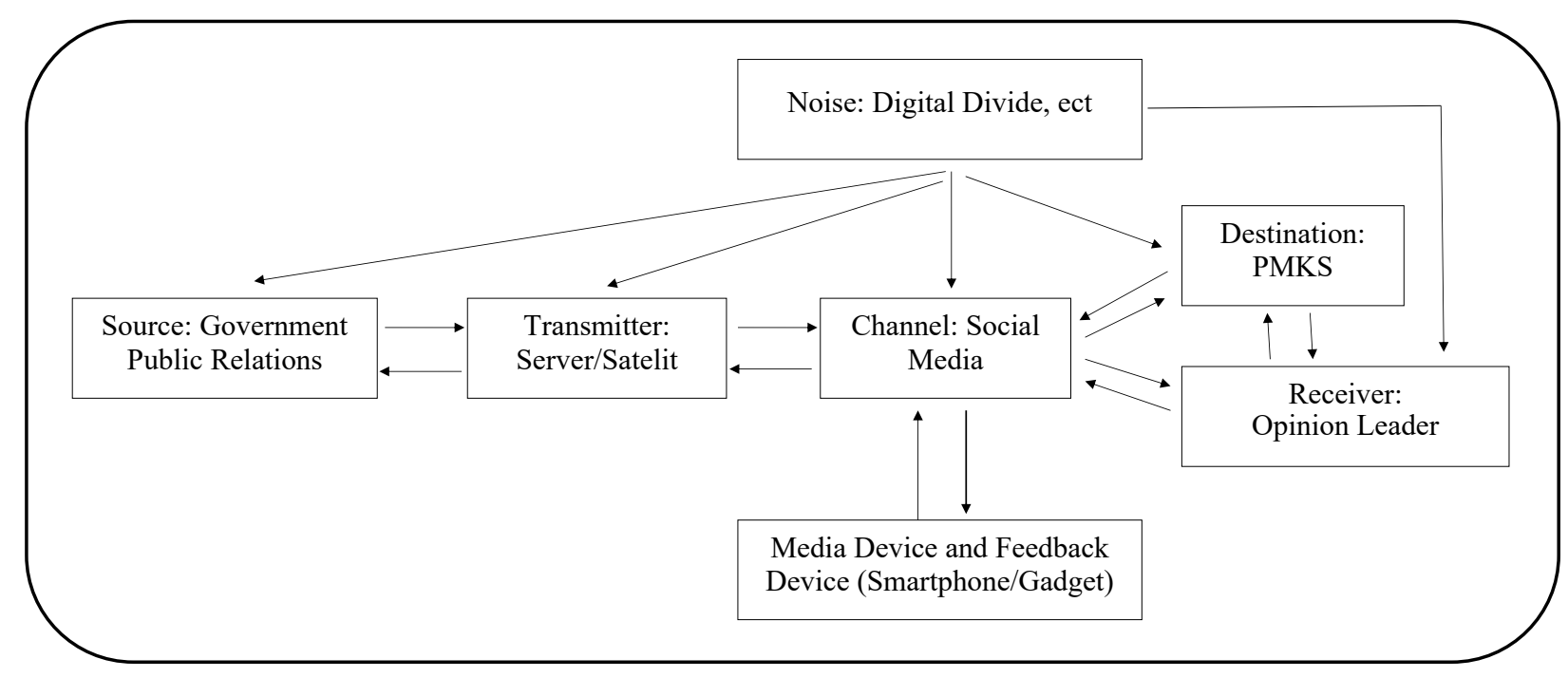

Figure 4. Research Findings Based on Modification of Melvin DeFleur Communication Model Source : Data analysis

\section{through Social media based on Melvin DeFleur Model}

Ideally, communication between Public Relations division, Ministry of Social Affairs with PMKS, through social media should be interactive. Nonetheless, the existence of the digital divide among PMKS, implies that there is an imbalance in the communication flow with the source of the information playing dominant role in influencing the process and outcome. Based on observation conducted by authors, which were complemented by results of interview with key informants, two patterns of communication between the Public Relations division, Ministry of Social Affairs and PMKS using social media were identified. The following sub section provides an elucidation of the two patterns.

1. Interactive communication between Public Relations Ministry of Social Affairs with PMKS

The communication process between Public Relations Ministry of Social Affairs and PMKS through social media in a mutual or two-way (bi directional) occurs in nature. Examples of such communications include convening of information by Ministry officials to the disabled who seek job information through Twitter, Facebook, and Instagram accounts of the Ministry of Social Affairs. Such communication bridges the information gap, which is part of the digital divide. Nonetheless, the above interactivity is generally limited to big cities where PMKS have access to digital media. That said, despite the limitation, in this case, communication activities of the PR division, Ministry of Social Affairs, through social media, has contributed to reducing the digital divide facing some elements of the population with disabilities in large urban areas. Figure 2, depicts the pattern of information flow that takes place.

2. Indirect communication involving interpersonal communication between opinion leaders and PMKS

This pattern shows that while due to some obstacles such as social and economic obstacles conditions that information recipients face, digital media may not reach its target directly, the existence of an intermediary, in this case a thought of opinion leader who has access to digital information, can mediate the message between the source and recipients, reducing the digital divide in the process. In this case opinion leaders, who are programs assistants serving Ministry of social affairs programs, including those that target PMKS, serve conveyors of program and policy related information to information to PMKS. The flow of information starts with the social media platforms of the Public Relations division, Ministry of So- 
cial Affairs, which opinion leaders pick up and subsequently to PMKS either directly or via short message and phone calls. Feedback to the information follows the same mechanism but in the reverse direction, starting with PMKS, opinion leaders, and social media account managers in the Ministry of social affairs. Thus, communication of information from the Ministry of Social affairs to PMKS as well as feedback information from the latter to the former, is indirect. An excerpt of an interview with informant who manages a foundation that takes care of street children in Purwakarta confirmed the existence of such a communication and feedback mechanism:

"Usually, if I get information or an email or phone call about social rehabilitation service, I immediately notify the children by paying a visit to their homes directly. Alternatively, if the child who has a cell phone, I call phone him or her. Like yesterday, of the three children I sent to SDC, one has a mobile phone. Nonetheless, sometimes I ask my employees for help in conveying the information.' (Interview with Purwakarta Street Children Foundation officials).

It is apparent that in this pattern of communication that is influenced by socioeconomic obstacles that PMKS recipients face, social media has not been able to bridge the digital divide (due to lack of access to communication and information technology). Nonetheless, PMKS through the influence of thought leaders have been able to receive the information that the Ministry of Social affairs tailored to them. This is because, thought leaders, have access to internal enabling them to be well informed and knowledgeable about programs and policies. The conclusion that can be drawn is that efforts by the Ministry of Social Affairs to reduce the digital divide that PMKS face which hampered the effectiveness of communication conveyed through social media by sending PMKS assistants has to a large extent been successful. Figure 3 depicts the pattern of the information flow.

This research uses Melvin DeFleur communication model to identify elements that are involved in the communication pro- cess between the Ministry of Social Affairs and PMKS through social media. The model proposes the notion that there are eight components in communication., inter alia, 1) The source : the source that produces and sends the information (can be people, institutions, etc.); 2) Transmitter: the operators of the signal uses to convey informant from the source to recipients; 3) Channel: the medium used to convey the information from source to recipient. This may take the form of mass media such as radio, TV, print media; 4) Receiver: the recipient of the signals that contains the information. This may take the form of human five senses which receive and process the message; 5) Destination: the target audience of the information (could be people, organization, etc.); 6) Noise: Any physical or psychological disturbance that affects the information transmission right from source to the destination; 7) Mass medium device: part of the channel or medium uses to convey information from source to destination; 8) Feedback device: Part of the feedback medium.

Using Melvin DeFleur communications model to show components of the communication process between the Public Relations division, Ministry of Social Affairs and PMKS, based on, with some modification, inter alia, include, 1) The Source: the Public relations division of the Ministry of Social Affairs; 2) Transmitter: information processor (server/computer/satellite); 3) Channel: Social media platforms (Twitter, Facebook, and Instagram); 4) Receiver: Opinion leader/Ministry of Social affairs field program officers/assistants; 5) Destination: PMKS individuals and group; 6) Noise: the Digital Divide; 7) Mass medium device: Gadget/smartphone; and 8) Feedback device: Gadget/smartphone

It is worth noting that in the above categorization of components of the communications process based on Melvin DeFleur communications model, authors modified the recipient component by substituting the original with the role of the opinion leaders. This was based on findings on the ground. To that end, the pattern of communication between the Public Relations division of the Ministry of Social Affairs and PMKS through social media is as depicted in in 
Sri Haryanti, Effy Zalfiana Rusfian - Government Public Relations and Social Media....

Figure 4.

Thus, based on Figure 4, information flow starts at the point of the Public Relations division Ministry of Social Affairs that produces the messages that are sent to servers and satellite. Subsequently, messages are disseminated through social media, which are transmitted via media devices such as smartphones. Messages either reach PMKS directly and or through the opinion leaders. Opinion leader spread forward messages to PMKS either through interpersonal communication or by making use of conventional telephone calls of short text messages The direction of the arrows reflect the bi directional flow of information. In other words, communication that occurs between the Ministry of Social affairs and PMKS is two way process.

In other words, based on empirical results that are informed by observation on the ground and results of interviews with key informants that are involved in the communication process, two patterns of communication between the PR, Ministry of Social Affairs and PMKS through social media were identified. The feedback that occurs is both direct and indirect. Meanwhile, the information flow takes two patterns, that is occurs in both one phase and two phases (this demands explanation for clarity). Knowledge of the communication pattern, feedback, and information flow in the communication process that occurs between PMKS and Ministry of Social Affairs through social media is beneficial for the government as it provides insights into how best to improve and enhance the effectiveness of communications services that are conducted by the public relations division. This is especially important in identifying the most appropriate communications media to reach certain groups of the public depending on the level of digital divide faced. Nonetheless, the information is also useful for the government if the underlying goal is to reduce disparity in the digital divide across sections and groups of society regions in the country.

To that end, DeFleur communication model is very relevant in portraying the two way communication process that occurs in the digital era, which is in constant flux.
DeFleur two-way communication model is a complete and comprehensive, which makes it ideal to portray any type of communication. This is the case at both the micro/ individual and institutional level, and meso level as in the case of the use of social media, Public Relations division, Ministry of Social Affairs in conveying information to PMKS. The model can with some minor modification, help to identify and portray the patterns of communications that occurs between government institutions and certain elements in society and level of interactivity thereof, highlighting obstacles that hamper its effectiveness, a process that informs future improvement efforts through social media. To that end, study findings underscore the importance of adopting a multistep or multiphase communication model to communicate government information to various groups in society who face varied access to digital media. While direct communication is possible for those sections of society with regular access to internet and digital devices, a combination of conventional and digital communications media involving final recipients and intermediaries, is essential in cases where information recipients face limited access to internet or social economic conditions hamper their ability to acquire digital devices that are essential for digital communication.

\section{CONCLUSION}

Based on research results, the use of social media on its own, is not sufficient to bridge the digital divide that PMKS, especially those living in rural and remote areas face. Key findings of this study both confirm and to some extent contest the notion that digital technology per se encourages the change in public communication. On the one hand, this research proves that social media as used by the Public Relations division, Ministry of Social Affairs has to a certain extent succeeded in bridging the digital divide (especially information gap) for people with social welfare problem. Nonetheless, this is limited to PMKS who live in urban areas and have access to digital technology. For PMKS in rural and remote areas, reducing or eliminating the digital divide, requires combination of the use of digital devices and 
conventional communication media to convey government information to PMKS members.

Research results underscore the transformation role that social media can play in global communication among components of society. Nonetheless, the transformation process can only occur if certain supporting conditions are in place, inter alia, availability of digital technology, access hence affordable digital devices, and enhanced digital literacy. For the public service, there is an additional requirement, which is reforming bureaucracy in general and significant reduction in red tape in the flow of information to recipients. In other words, authors of this paper concur with of public relations professionals opinion that role of digital PR in government has been to extend rather than transform, existing relations, communications, and interaction (Holtz, 2002).

Based on research results, authors propose several recommendations. The use of digital media and technology as a medium to convey public policy, within the context of society that face disparity in digital access, may instead accentuate not only the digital divide, but also social and economic inequality. To that end, using digital technology in public policy needs rethinking and revisiting While the study confirms previous empirical findings that support the vital role that social media plays in improving communication across the globe, differences in resources, social, economic and cultural institutions influence access to digital media, hence may not quick fix for all groups in society and across regions even in single country. Thus, effective communications in Indonesia, given social, economic, and cultural conditions that have fostering the existence of digital divide across society groups, effective communication of public policy cannot be based on digital media alone but must involve a combination of both digital and conventional communication media.

\section{REFERENCES}

Adhrianti, L. (2017). Digitalisasi Public Relations Bagi Penguatan Citra Pemerintah Daerah (Analisis Deskriptif Reaktualisasi Peran $\mathrm{Hu}-$ mas Pemerintah Kota Bengkulu dalam Penyampaian Informasi Daerah Melalui Media Sosial). Prosiding Komunikasi, 1 (2), 115-125.

Ahn, J. (2011). Digital Divides and Social Network Sites: Which Students Participate In Social Media? Journal Educational Computing Research, 45 (2), 147-163.

Ariyanti, S. (2013). Studi Pengukuran Digital Divide di Indonesia. Buletin Pos dan Telekomunikasi, 11(4), 281-292.

Baskin, O., \& Aronoff, C. (2012). Public Relations: The Profession and the Practice. Boston: McGraw-Hill.

Brown, H. (2015). The Institutional Digital Divide: Immigrant-Serving Nonprofit Organization Adoption of Social Media. Social Science Computer Review, 33(6), 680-695.

Brown, R. (2009). Public Relations and the Social Web: Using Social Media and Web 2.0 in Communication. London: Kogan Page.

Butterick, K. (2013). Pengantar Public Relations Teori dan Praktik. Jakarta: Raja Grafindo.

Calderaro, A. (2010). The Digital Divide, Framing and Mapping the Phenomenon. In E. e. Ferro, Handbook of Research on Overcoming Digital Divides (pp. 21-39). New York: Information Science Reference.

Corrocer, N., \& Raineri, A. (2010). The Evolution of the Digital Divide Across Developing Countries. In E. e. Ferro, Handbook of Research on Overcoming Digital Divides (pp. 5874). New York: Information Science Reference.

Daymon, C., \& Holloway, I. (2011). Qualitative Research Method in Public Relations and Marketing Communications, 2nd Ed. New York: Routledge.

Graham, M. W. (2014). Government Communication in the Digital Age: Social's Media Effect on Local Government Public Relations. Public Relations Inquiry, 3(3), 361-376.

Grunig, L., Grunig, J., \& Dozier, D. (2002). Excellent Public Relations and Effec- 
tive Organizations. New Jersey: Lawrence Erlbaum Associates.

Gunawong, P. (2015). Open Government and Social Media: A Focus on Transparency. Social Science Computer Review, 33(5), 587-598.

Haro-de-Rosario, A., Alejandro, S., and Caba-Perez, M.D.C. (2018). Using Social Media to Enhance Citizen Engagement with Local Government: Twitter or Facebook? New Media \& Society, 20 (1), 29-49. doi: $10.1177 / 1461444816645652$

Holtz, S. (2002). Public Relations on the Net: Winning Strategies to Inform and Influence the Media, the Investment Community, the Government, the Public, and More! 2nd Ed. New York: Amacom.

Kaul, A., \& Choudhry. (2015). Social Media: The New Mantra for Managing Reputation. The Journal for Decision Makers, 40 (4), 455-491.

Kementerian Sosial RI. (2015). Rencana Strategis 2015-2019. Retrieved from http://mail.kemsos.go.id/home/ tira@kemsos.go.id/Briefcase/ PUBLIC\%20RESTRA/RENSTRA\% 20DIT\%20Anak\%202015-2019.pdf

Kementerian Sosial RI. (2017). Facebook @)KemsosRI.

Kementerian Sosial RI. (2017). Instagram @kemensosri.

Kementerian Sosial RI. (2017). Twitter (a) KemensosRI.

Khan, G. F. (2017). Social Media for Government: A Practical Guide to Understanding, Implementing, and Managing Social Media Tools in the Public Sphere. Singapore: Springer.

Kusumasari, B. (2014). Social Media dan Eksklusi Remaja dalam Perumusan Kebijakan Publik. Jurnal Kebijakan dan Administrasi Publik, JKAP, 18 (2), 119-129.

Laskin, A. (2009). The Evolution of Models of Public Relations: An Outsider's Perspective. Journal of Communication Management, 13(1), 37-54.

Miniwatts Marketing Group. (2017, June). Top 20 Countries With The Highest Number of Internet User. Retrieved from https:// www.internetworldstats.com/ top20.htm

Munandar, H., \& Suherman, M. (2016). Aktivitas Komunikasi Pemerintahan Ridwan Kamil di Media Sosial. Prosiding Hubungan Masyarakat, 2(1). 423-430

Nepal, S., Paris, C., \& Georgakopolus, D. (2015). Social Media for Government Services. Switzerland: Springer.

Nuemann, W. L. (2013). Metodologi Penelitian Sosial: Pendekatan Kualitatif dan Kuantitatif, 7th ed. Jakarta: Indeks.

Philips, D., \& Young, P. (2009). Online Public Relations: A Practical Guide to Developing an Online Strategy in the World of Social Media, 2nd ed. London: Kogan Page.

Riatika, N. (2014, Januari). Analisis Penggunaan Youtube Pemerintah DKI Jakarta sebagai Sarana Transparansi Komunikasi Ditinjau dari Sudut Pandang Poltical PR. Retrieved from http://lib.ui.ac.id/detail? id $=20368883 \&$ lokasi $=$ lokal

Scott, P. R., \& Jacka, J. M. (2011). A uditing Social Media: A Governance and Risk Guide. New Jersey: John Wiley and Sons, Inc.

Sendjaja, S. J. (2008). Modul Pengantar Ilmu Komunikasi. Retrieved from http://www.pustaka.ut.ac.id/ lib/2016/08/08/skom4101-pengantarilmu-komunikasi-edisi-3/

The Civil Society and Media Team USAID. (2014). Social Networking: A Guide to Strengthening Civil Society through Social Media. Retrieved from www.usaid.gov/ SMGuide4CSO.

Theaker, A. (2004). The Public Relations Handbook, 2nd Ed. New York: Routledge.

Tsetsi, E., \& Rains, S. A. (2017). Smartphone Internet Access and Use: Extending the Digital Divide and Usage Gap. Mobile Media \& Communication, 5(3), 239-255.

Tyas, D. L. (2015). Pengaruh Kekuatan Me- 
dia Sosial dalam Pengembangan Kesenjangan Digital. Scientific Journal of Informatics, 2(2), 147-154.

Vardiansyah, D. (2004). Pengantar Ilmu Komunikasi. Bogor: Ghalia Indonesia.

Vistbacka, S. (2017). Crisis Management in Social Media - Maintaining the Organizational Image. Jyväskylän Yliopisto: Jyväskylä University. Retrieved from https://jyx.jyu.fi/ bitstream/ handle/123456789/54477/1/URN\% 3ANBN\%3Afi\%3Ajyu201706142855.pdf
White, A. (2014). Digital Media and Society: Transforming Economics, Politics and Social Practices. Hampshire: Palgrave Macmillan. 